\title{
Pengelolaan ruang terbuka hijau berbasis ekosistem mangrove sebagai mitigasi gas rumah kaca di kawasan Sungai Tallo Kota Makassar
}

\section{Green open spaces management based on mangrove ecosystem as a mitigation of greenhouse gases in Tallo River area of Makassar City}

\author{
Rahman $^{\mathrm{a}}$, Hefni Effendi ${ }^{\mathrm{b}, \mathrm{c}}$, Iman Rusmana $^{\mathrm{d}}$, Fredinan Yulianda ${ }^{\mathrm{b}}$, Yusli Wardiatno ${ }^{\mathrm{b}, \mathrm{c}}$ \\ a Program Doktoral Pengelolaan Sumberdaya Pesisir dan Lautan, Sekolah Pascasarjana IPB, Kampus IPB Darmaga Bogor, 16680, \\ Indonesia [+62 2193576093] \\ ${ }^{\mathrm{b}}$ Departemen Manajemen Sumberdaya Perairan, Fakultas Perikanan dan Ilmu Kelautan, Institut Pertanian Bogor, Kampus IPB \\ Darmaga Bogor, 16680, Indonesia \\ ${ }^{c}$ Pusat Penelitian Lingkungan Hidup, Institut Pertanian Bogor, Kampus IPB Darmaga Bogor, 16680, Indonesia \\ ${ }^{\mathrm{d}}$ Departemen Biologi, Fakultas Matematika dan Ilmu Pengetahuan Alam, Institut Pertanian Bogor, Kampus IPB Darmaga Bogor, \\ 16680, Indonesia
}

\section{Article Info:}

Received: 20 - 04 - 2020

Accepted: 31 - $05-2020$

\section{Keywords:}

Green open space, greenhouse gas mitigation, mangrove ecosystem management, Tallo river, Makassar city.

\section{Corresponding Author:}

Yusli Wardiatno

Departemen Manajemen

Sumberdaya Perairan, Fakultas

Perikanan dan Ilmu Kelautan,

Institut Pertanian Bogor;

Tel. +628128608966

Email:

yusli@ipb.ac.id

\begin{abstract}
One of the ecological functions of mangroves ecosystem is to store carbon. Yet, on the other hand it is potentially to cause greenhouse gas emissions through litter degradation even though its value is lower compared to the absorption value. Based on these two facts, mangrove management as a Green Open Space in the Tallo River area of Makassar City needs to consider involving the participation of the community and the government as stakeholders. This study aimed to analyze the carbon adsorbance and global warming potential of the mangrove ecosystem as a basis for managing green open spaces in Makassar City. The research was conducted by desk work, literature study and respondent interviews regarding perceptions and participation in mangrove management. The results showed that the total uptake of mangrove carbon in the Tallo River in Makassar city was 351.02 tons $\mathrm{CO}_{2} / \mathrm{ha}$, oxygen supply $255.29 \mathrm{O}_{2}$-equivalent/ha, and the potential for global warming was $252.41 \mathrm{mg} / \mathrm{m}^{2} /$ hour consisting of $194.33 \mathrm{mg} / \mathrm{m}^{2} /$ hour of $\mathrm{CO}_{2}$ gas, $15.76 \mathrm{mg} / \mathrm{m}^{2} /$ hour of $\mathrm{CH}_{4}$ gas, and $42.33 \mathrm{mg} / \mathrm{m}^{2} /$ hour of $\mathrm{N}_{2} \mathrm{O}$ gas. The results of community perception and participation analysis show that around $89 \%$ of the community strongly agreed and supported the government in the effort to manage mangroves as a green open space. Based on these facts, the ecosystem in Tallo river is very suitable to manage for green open space as fresh air supplier and $\mathrm{CO}_{2}$ adsorber as well as a noise reduction from vehicle or industrial engines in Makassar city.
\end{abstract}

How to cite (CSE Style $8^{\text {th }}$ Edition):

Rahman, Effendi H, Rusmana I, Yulianda F, Wardiatno Y. 2020. Pengelolaan ruang terbuka hijau berbasis ekosistem mangrove sebagai mitigasi gas rumah kaca di kawasan Sungai Tallo Kota Makassar. JPSL 10(2): 320-328. http://dx.doi.org/10.29244/jpsl.10.2.320328. 


\section{PENDAHULUAN}

Gas rumah kaca (GRK) merupakan komponen gas yang memiliki peran dalam menentukan suhu di atmosfer melalui penyerapan radiasi inframerah. Emisi gas rumah kaca terus mengalami peningkatan akibat dari aktivitas manusia bahkan dimulai sejak era pra industri (IPCC, 2001). Peningkatan gas rumah kaca di atmosfer berpotensi memicu terjadinya pemanasan global (KLH, 2012).

Pemanasan global merupakan salah satu peristiwa penting yang cukup ditakuti, bukan saja di Indonesia, tetapi juga berkembang menjadi isu global yang dibicarakan oleh hampir seluruh kalangan internasional (Riani, 2012). GRK utama dan terbesar dalam memicu terjadinya pemanasan global adalah karbon dioksida $\left(\mathrm{CO}_{2}\right)$ dan metana $\left(\mathrm{CH}_{4}\right)$. GRK ini dihasilkan dari berbagai aktivitas manusia terutama pembakaran bahan bakar fosil baik pada kendaraan bermotor maupun industri yang menyebabkan terjadi akumulasi GRK (IPCC, 2001). Selain gas $\mathrm{CH}_{4}$ dan $\mathrm{CO}_{2}$, GRK lain yang juga memiliki potensi dalam memicu perubahan iklim adalah gas nitrous oxide atau yang dikenal dengan $\mathrm{N}_{2} \mathrm{O}$. Menurut IPCC (2007), emisi GRK saaat ini meningkat hingga 70\% pada rentang waktu 1970-2004. DeFries et al. (2002) menyatakan bahwa aktivitas penebangan pohon memiliki kontribusi yang besar dalam menambah karbon ke atmosfer, sehingga berpotensi terhadap peningkatan GRK. Disisi lain berbagai upaya pengalihan fungsi ruang terbuka hijau menjadi lahan pemukiman baik yang ada di tengah perkotaan maupun di wilayah pesisir terus terjadi yang akhirnya menyebabkan stok dan serapan karbon mangrove menjadi berkurang.

Kota Makassar adalah pusat Indonesia Timur. Upaya pembangunan telah dilakukan pemerintah demi mewujudkan Makassar sebagai kawasan terkemuka di Indonesia timur. Gejala pembangunan di wilayah perkotaan membawa konsekuensi meningkatnya kebutuhan ruang untuk pembangunan kota sehingga penggunaan lahan potensial sebagai ruang terbuka hijau mengalami penurunan yang sangat drastis.

Pembangunan ruko-ruko telah menjadi pilihan bagi masyarakat dan pemerintah Kota Makassar. Hampir menyeluruh di sepanjang jalan kota Makassar, dari pinggiran kota hingga pusat kota semua rumah disulap menjadi 'double-set' yakni rumah-toko. Selain itu alih fungsi kawasan ruang terbuka hijau (RTH) seperti RTH kawasan pusat perbelanjaan (Mal Karebosi) di tengah Kota Makassar yang telah direnovasi dan sebagian daerahnya dialihfungsikan menjadi pusat perbelanjaan, padahal sejak lama kawasan karebosi dikenal memiliki peran penting dalam menetralisasi intrusi air laut karena lokasinya yang dekat dengan pesisir Kota Makassar. Luas Kota Makassar adalah 175 km² dan munurut UU No. 26 Tahun 2007 kebutuhan RTH kawasan perkotaan mencapai 30\%. Berdasarkan luas tersebut, maka Kota Makassar membutuhkan RTH sekitar 5 ribu hektar. Saat ini RTH Kota Makassar kurang dari 10\% sedangkan menurut Rijal (2008) bahwa RTH Makassar masih di bawah standar yang telah ditetapkan oleh World Health Organisation (WHO). WHO menetapkan bahwa untuk setiap kota harus memiliki kawasan hijau $9 \mathrm{~m}^{2}$ per penduduk, sementara saat ini Kota Makassar hanya memiliki $3 \mathrm{~m}^{2}$ per penduduk. Keberadaan RTH di kawasan Kota Makassar dapat meminimalisasi potensi tercemarnya udara, mencegah banjir, dan menyuplai udara bersih. Oleh karena itu, diperlukan kawasan baru yang dapat menjadi alternatif RTH di Kota Makassar.

Salah satu lahan yang sangat potensial untuk dikembangkan sebagai RTH dalam upaya dalam mitigasi GRK di Kota Makassar adalah ekosistem mangrove di di bantaran Sungai Tallo. Kawasan ini dikelilingi oleh vegetasi mangrove yang beragam dan di dominasi oleh jenis Nypah, Avicennia dan Rhizophora (Rahman et al., 2017).

Pengelolaan ekosistem mangrove sebagai kawasan RTH sangatlah tepat karena mampu menyerap gas $\mathrm{CO}_{2}$ yang ada di atmosfer, sehingga dapat mengurangi efek perubahan iklim global akibat GRK. Menurut Komiyama et al. (2008) bahwa ekosistem sangat berperan dalam meminimalisir efek GRK sehingga dapat memitigasi perubahan iklim. Mekanisme reduksi GRK pada ekosistem mangove terjadi melalui penyerapan karbon. Selanjutnya karbon disimpan dalam tegakan yaitu berupa biomassa dan pada substrat yaitu berupa serasah (Hairiah dan Rahayu, 2007). Menurut penelitian Rahman et al. (2017) bahwa total serapan karbon di wilayah sungai Tallo Kota Makassar yaitu 351.02 tonCO $2 /$ ha. 
Selain menyerap karbon, pada ekosistem mangrove juga terjadi fluks gas rumah kaca seperti $\mathrm{CH}_{4}, \mathrm{CO}_{2}$ maupun $\mathrm{N}_{2} \mathrm{O}$ (Allen et al., 2007; Biswas et al., 2007; Davidson, 2009; Dunne et al., 2013). Gas $\mathrm{CO}_{2}$ terbentuk melalui proses dekomposisi bahan serasah oleh mikroba namun dengan konsentrasi yang lebih kecil dibandingkan dengan gas $\mathrm{CH}_{4}$ (Nobrega et al., 2016). Menurut IPCC (2001), bahwa emisi gas $\mathrm{CH}_{4}$ yang terdapat di atmosfer sekitar $70 \%$ berasal dari aktivitas antropogenik dan $30 \%$ berasal dari alam. $\mathrm{Gas}_{2} \mathrm{O}$ terbentuk dari aktivitas mikroorganisme dalam tanah melalui proses reaksi kimia berupa nitrifikasi ataupun denitrifikasi serta aktivitas manusia berupa penggunaan bahan bakar fosil, biomass, dan agriculture (Davidson et al., 2000; IPCC, 2001). Adanya fluks gas rumah kaca tersebut menimbulkan potensi terjadinya pemanasan global dengan tingkat radiasi tertentu. Berdasarkan permasalahan tersebut maka penelitian ini bertujuan untuk menganalisis serapan karbon dan potensi pemanasan global ekosistem mangrove sebagai dasar dalam pengelolaannya untuk ruang terbuka hijau sehingga dapat memitigasi gas rumah kaca di Kota Makassar.

\section{METODE}

\section{Metode Pengumpulan Data}

\section{Studi Literatur terkait Serapan Karbon dan Potensi Pemanasan Global}

Pengumpulan data terkait serapan karbon ekosistem mangrove di Sungai Tallo Kota Makassar mengacu pada hasil penelitian Rahman et al. (2017), sedangkan nilai potensi pemanasan global dihitung dengan menganalisis nilai $\mathrm{CO}_{2}$ equivalent dari fluks gas rumah kaca berdasarkan penelitian Rahman et al. (2018).

\section{Data Persepsi dan Partsipasi Masyarakat}

Dalam upaya pengelolaan suatu ekosistem maka dukungan dan partisipasi masyarakat sangat ditentukan oleh persepsi masyarakat itu sendiri. Berdasarkan kondisi tersebut maka untuk mengetahui persepsi masyarakat di sekitar bantaran Sungai Tallo khususnya di Kecamatan Tallo dilakukan dengan pengisian kuesioner wawancara mendalam terhadap responden yang dipilih secara purposive sampling. Responden yang dipilih adalah masyarakat atau pihak yang memiliki keterkaitan dengan kawasan mangrove seperti petani tambak, pelaku wisata, tokoh masyarakat, pemerintah desa, dan pejabat pemerintahan Kota Makassar.

\section{Metode Analisis Data}

Analisis data serapan karbon dilakukan secara deskiptif kuantitatif berdasarkan hasil penelitian yang telah dilaporkan Rahman et al. (2017). Nilai suplai oksigen $\left(\mathrm{O}_{2}\right)$ dihitung berdasarkan hasil perkalian nilai serapan karbon dengan perbandingan nilai massa molekul (Mr) oksigen terhadap massa molekul karbon dioksida. Formula perhitungan tersebut dapat ditulis sebagai berikut:

$$
\text { Suplai oksigen }(\text { tonO } 2 / \text { ha })=\frac{M r O 2}{M r C O 2} \times \text { serapan } \mathrm{CO}_{2}(\text { tonCO } 2 / \text { ha })
$$

Dimana $\mathrm{Mr}_{2}$ adalah $32 \mathrm{gram} / \mathrm{mol}$ dan $\mathrm{MrCO}_{2}$ sebesar 44 gram $/ \mathrm{mol}$. Sedangkan analisis nilai $\mathrm{CO}_{2}$-equivalent dihitung berdasarkan nilai potensi pemanasan global atau Global Warming Potential (GWP) dari masingmasing fluks gas rumah kaca menurut (Rahman et al., 2018). Formula untuk menghitung nilai tersebut mengacu pada persamaan $\operatorname{IPCC}(1990,2001)$ yaitu sebagai berikut:

$$
\mathrm{CO}_{2} \text { equivalent }=\mathrm{Fm} \times \mathrm{GWP}
$$

Dimana $\mathrm{CO}_{2}$-equivalent adalah nilai potensi pemanasan global dari gas rumah kaca, $\mathrm{Fm}$ adalah nilai fluks gas rumah kaca $\left(\mathrm{CH}_{4}\right.$ dan $\left.\mathrm{N}_{2} \mathrm{O}\right)$, sedangkan GWP adalah nilai potensi pemanasan global yaitu masing-masing 23 untuk gas $\mathrm{CH}_{4}$ dan 296 untuk gas $\mathrm{N}_{2} \mathrm{O}$. 


\section{Analisis Persepsi dan Partisipasi Masyarakat}

Analisis dilakukan dengan menghitung persentase responden terhadap jawaban tertentu, kemudian menganalisis secara deskriptif berdasarkan kecenderungan jawaban dari sejumlah responden.

\section{Analisis Pengelolaan Ekosistem Mangrove sebagai Ruang Terbuka Hijau}

Analisis ini dilakukan secara deskriptif dan didasarkan pada serapan karbon ekosistem mangrove, tingkat pemanasan global, dan peranan pemerintah serta persepsi masyarakat. Seluruh analisis tersebut diharapkan menjadi rujukan bagi pemangku kebijakan dalam menetapkan pengelolaan ekosistem mangrove untuk RTH sebagai upaya mitigasi GRK di Kota Makassar.

\section{HASIL DAN PEMBAHASAN}

\section{Serapan Karbon dan Potensi Pemanasan Global}

Berdasarkan hasil analisis pada laporan penelitian Rahman et al. (2017) didapatkan bahwa total serapan karbon ekosistem mangrove di kawasan Sungai Tallo yaitu 351.02 tonCO $/$ ha yang terdiri dari 80.02 tonCO $\mathrm{C}_{2}$ /ha serapan karbon Nypa fruticans, 73,13 tonCO 2 /ha serapan karbon Rhizophora mucronata, dan 197.87 tonCO $\mathrm{C}_{2}$ /ha serapan karbon Avicennia alba (Gambar 1). Nilai serapan karbon tersebut relatif tinggi dibandingkan dengan Rachmawati et al. (2014) dan lebih rendah dibandingkan dengan Heriyanto dan Subiandono (2012); Siddique et al. (2012); Alemayehu et al. (2014) yang berkisar antara 398.60 hingga 1085.33 tonCO $\mathrm{CO}_{2} / \mathrm{ha}$. Perbedaan nilai serapan karbon ekosistem mangrove antara satu lokasi terhadap lokasi lainnya secara umum disebabkan oleh adanya perbedaan kerapatan mangrove, nilai diameter at breast height $(\mathrm{DBH}=130 \mathrm{~cm})$, dan komposisi spesies mangrove yang terdapat pada masing-masing ekosistem. Adapun nilai karbon yang tersimpan di substrat mangrove (Below Ground Biomass) selain faktor tersebut, juga dipengaruhi oleh tipe habitat misalnya lumpur, pasir atau lainnya serta fluktuasi pasang surut. Hasil analisis menunjukkan bahwa total suplai oksigen ekosistem mangrove di Sungai Tallo Kota Makassar yaitu 252.29 ton $\mathrm{O}_{2}$ /ha yang terdiri dari 58.20 ton $\mathrm{O}_{2}$ /ha dari suplai $N$. fruticans, 53.19 tonO $\mathrm{O}_{2}$ /ha dari Rhizophora mucronata, dan $143.91 \mathrm{tonO}_{2}$ /ha dari suplai A. alba (Gambar 1). Nilai suplai oksigen tersebut merupakan suplai oksigen equivalent terhadap nilai $\mathrm{CO}_{2}$-equivalent dan tidak menunjukkan laju proses fotosinstesis. Meski demikian, serapan karbon dan suplai oksigen tersebut mampu menunjukkan kontribusi ekosistem mangrove terhadap perbaikan kualitas udara di Kota Makassar baik melalui pengurangan emisi $\mathrm{CO}_{2}$ maupun suplai udara segar.

Nilai serapan karbon dan suplai oksigen pada suatu ekosistem dapat mengalami kenaikan seiring dengan bertambahnya diameter dan kerapatan mangrove. Peningkatan kerapatan mangrove secara alami melalui produksi semai (Rahman et al., 2019) dan rekayasa antropogenik yaitu melalui rehabilitasi mangrove dengan kerjasama diantara para pemangku kepentingan seperti masyarakat, lembaga swadaya masyarakat, dan pemerintah (Oni et al., 2019). Kegiatan rehabilitasi ekosistem mangrove yang baik juga berfungsi menjaga kelestarian ekosistem mangrove sehingga tidak mengalami krisis lahan seperti yang terjadi di Kota Langsa (Iswahyudi et al., 2020) yang disebabkan oleh alih fungsi lahan sebagai tambak, pemukiman, atau infrastruktur lainnya (Ilman et al., 2016 dan Rahman et al., 2020). Alih fungsi lahan mangrove menjadi tambak dapat saja dilakukan dengan proporsi tertentu dan pertimbangan keuntungan ekonomi. Hal ini didukung penelitian terkini bahwa budidaya tambak udang mampu menyerap $\mathrm{CO}_{2}$ hingga $25 \%$ dari serapan karbon mangrove melalui penyerapan fitoplankton. Selain itu, emisi gas $\mathrm{CH}_{4}$ yang dihasilkan tambak tradisional, semi intensif, dan intensif juga relatif rendah yaitu berkisar 0.00005 hingga $0.00955 \mathrm{mg} / \mathrm{m}^{2} / \mathrm{menit}$ (Rifqi et al., 2020a; 2020b). 


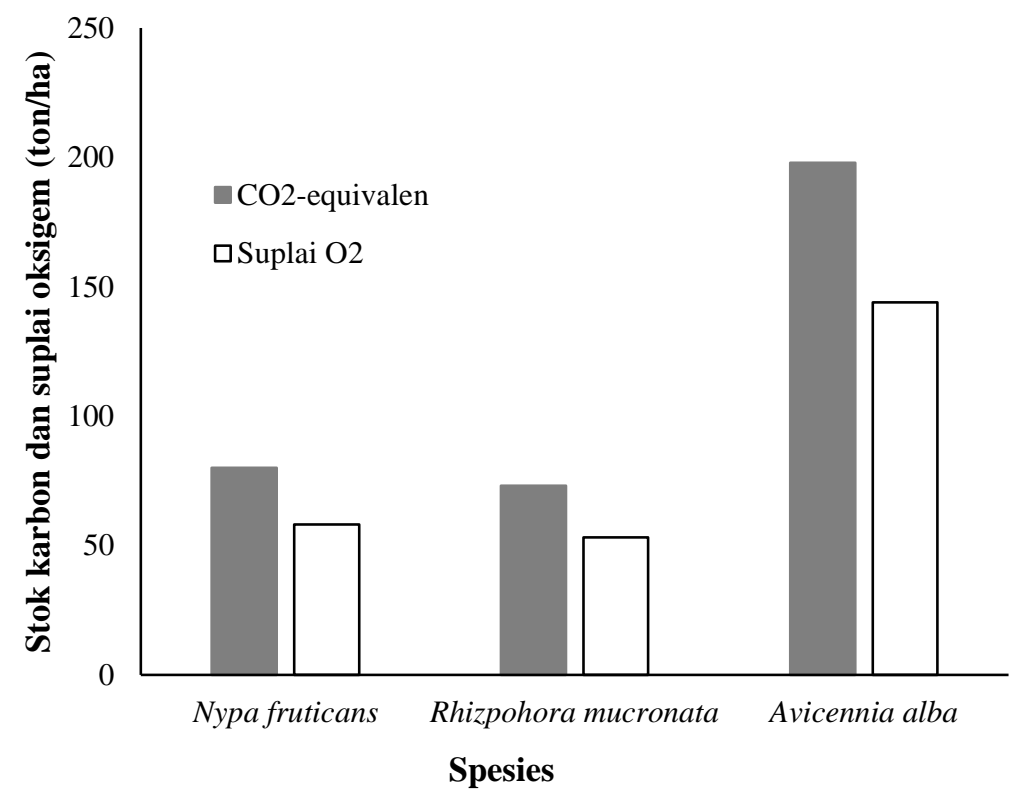

Gambar 1 Nilai serapan karbon $\left(\mathrm{CO}_{2}\right.$-equivalent ton/ha) dan suplai oksigen $\left(\mathrm{O}_{2}\right.$-equivalent ton/ha) di ekosistem mangrove Sungai Tallo, Kota Makassar (diolah dari Rahman et al., 2017)

Hasil analisis terhadap nilai potensi emisi karbon dari laporan Rahman et al. (2018) menunjukkan bahwa nilai $\mathrm{CO}_{2}$-equivalent total GRK di Sungai Tallo Kota Makassar yaitu $252.41 \mathrm{mg} / \mathrm{m}^{2} / \mathrm{jam}$ yang terdiri dari $194.33 \mathrm{mg} / \mathrm{m}^{2} / \mathrm{jam}$ gas $\mathrm{CO}_{2}, 15.76 \mathrm{mg} / \mathrm{m}^{2} / \mathrm{jam}$ gas $\mathrm{CH}_{4}$, dan $42.33 \mathrm{mg} / \mathrm{m}^{2} / \mathrm{jam}$ gas $\mathrm{N}_{2} \mathrm{O}$ (Tabel 1). Nilai potensi emisi $\mathrm{CO}_{2}$ tersebut sangatlah rendah jika dibandingkan dengan total serapannya, sehingga nilai emisi karbon tersebut dapat diabaikan kaitannya dengan kontribusi terhadap gas rumah kaca di atmosfir atau terhadap potensi pemanasan global itu sendiri (Sotomayor et al., 1994). Meski demikian, nilai emisi karbon tersebut harus selalu dipertahankan dengan cara menjaga kondisi ekosistem mangrove di Sungai Tallo termasuk lingkungan perairannya terutama yang berkaitan dengan input limbah domestik maupun limbah industri.

Tabel 1 Nilai potensi emisi $\mathrm{CO}_{2}\left(\mathrm{CO}_{2}\right.$-equivalent $)$ GRK di ekosistem mangrove Sungai Tallo, Kota Makassar

\begin{tabular}{lcccc}
\hline \multirow{2}{*}{ Kondisi perairan } & \multicolumn{4}{c}{$\mathrm{CO}_{2}$-equivalent $\left(\mathrm{mg} / \mathrm{m}^{2} / \mathrm{jam}\right)$} \\
\cline { 2 - 5 } & $\mathrm{N}_{2} \mathrm{O}$ & $\mathrm{CH}_{4}$ & $\mathrm{CO}_{2}$ & Total \\
\hline Pasang & 41.74 & 17.25 & 204.84 & 263.83 \\
Surut & 42.92 & 14.26 & 183.81 & 240.99 \\
Rerata & 42.33 & 15.76 & 194.33 & 252.41 \\
\hline
\end{tabular}

Diolah dari Rahman et al. (2018)

\section{Partisipasi Masyarakat dalam Pengelolaan Ekosistem Mangrove}

Pengelolaan ekosistem mangrove tak terlepas dari peran masyarakat. Hal ini karena masyarakat adalah pelaku dan sasaran dari suatu pengelolaan. Hasil analisis tanggapan masyarakat yang hidup di kawasan ekosistem mangrove Sungai Tallo terhadap keberadaan dan fungsi ekosistem mangrove berdasarkan wawancara langsung kepada 50 responden (masyarakat) yang diwakili oleh kepala keluarga menunjukkan bahwa secara umum masyarakat sepakat terhadap keberadaan ekosistem mangrove dengan segala fungsi dan manfaatnya (Gambar 2). Sekitar 27 orang atau 54\% dari 50 responden menjawab bahwa mangrove tepat dimanfaatkan sebagai ruang terbuka hijau penyuplai udara segar dan 23 orang atau $46 \%$ sisanya menjawab sangat tepat. Selanjutnya, sebanyak 24 orang atau $48 \%$ menyatakan bahwa mangrove tepat sebagai penurun emisi gas rumah kaca, sedangkan 15 orang atau $30 \%$ menyatakan sangat tepat dan sisanya $22 \%$ menyatakan sebaliknya. Tanggapan masyarakat terkait fungsi mangrove sebagai penyaring dan penahan banjir sebanyak 
$34 \%$ dan $66 \%$ masing-masing menyatakan tepat dan sangat tepat. Hal ini dapat terjadi karena masyarakat sadar akan fungsi utama mangrove berdasarkan pengalaman-pengalaman selama mereka hidup di kawasan tersebut yang mana mereka sangat jarang mengeluh akan panasnya terik matahari dan suhu udara seperti apa yang dirasakan oleh masyarakat di pusat perkotaan Kota Makassar.

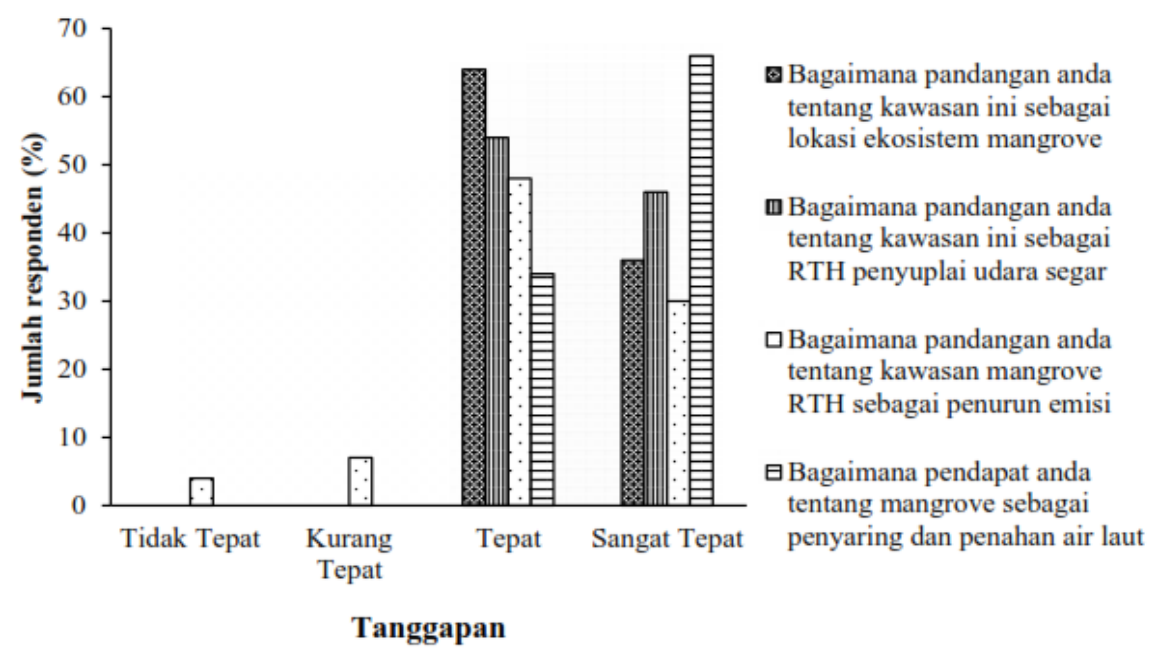

Gambar 2 Tanggapan masyarakat terhadap ekosistem mangrove Sungai Tallo, Kota Makassar dan fungsi ekologinya

Hasil analisis partisipasi masyarakat terhadap keterlibatan dalam pengelolaan ekosistem mangrove menunjukkan bahwa sekitar 38 orang atau $76 \%$ dari 50 responden masyarakat setuju, sisanya 12 orang masingmasing $10 \%$ tidak setuju dan 14\% kurang setuju akan adanya perwakilan masyarakat dalam pengelolaan ekosistem mangrove. Sementara itu, untuk setiap kebijakan yang akan ditetapkan oleh pemerintah terkait pengelolaan mangrove, sekitar 54\% masyarakat kurang setuju dengan kebijakan pengelolaan yang tidak melalui sosialisasi. Wawancara lebih lanjut kepada masyarakat terkait kebijakan pemerintah menunjukkan bahwa $86 \%$ masyarakat menginginkan agar pemerintah mengonsultasikan setiap kebijakan yang akan ditetapkan terutama jika kebijakan tersebut berkenaan dengan hajat hidup mereka. Adapun untuk waktu keterlibatan, sekitar 90\% masyarakat sangat setuju untuk berpartisipasi selama kegiatan pengelolaan sebagai bentuk tanggung jawab terhadap lingkungan (Gambar 3).

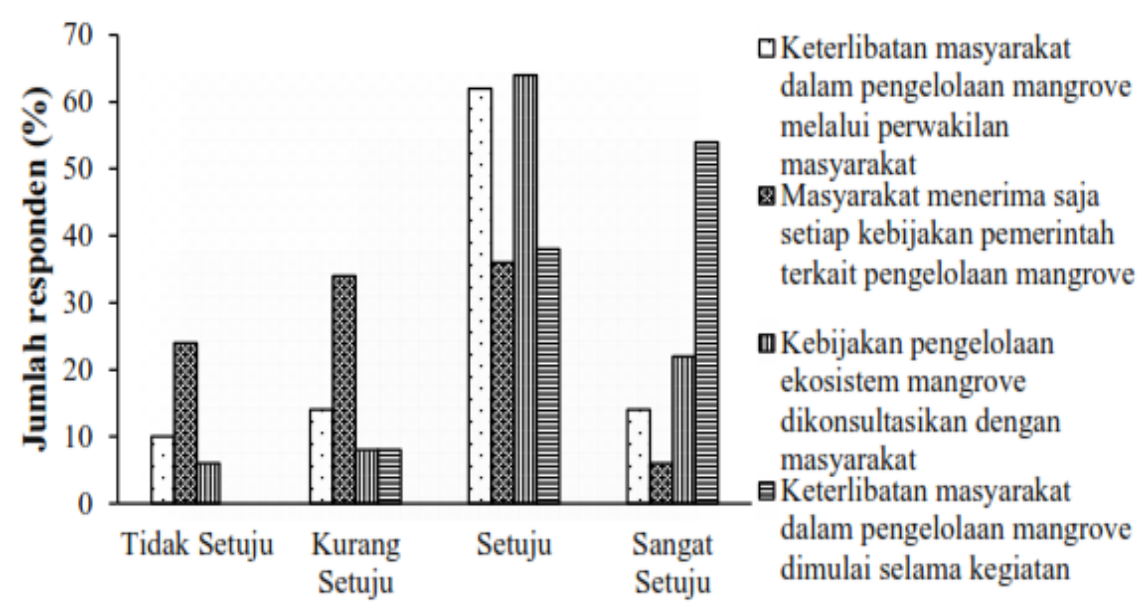

Partisipasi

Gambar 3 Tingkat partisipasi masyarakat terhadap pengelolaan ekosistem mangrove Sungai Tallo, Kota Makassar 


\section{Ekosistem Mangrove sebagai RTH}

Menurut Wijanarko (2006) RTH merupakan areal permukaan tanah yang didominasi oleh tumbuhan tertentu dengan fungsi sebagai kawasan konservasi habitat tertentu, sarana lingkungan, pengamanan jaringan prasarana, serta budidaya pertanian. Lebih lanjut, RTH juga berperan untuk meningkatkan kualitas udara, menunjang kelestarian air dan tanah, dan meningkatkan kualitas lanskap kota.

Sungai Tallo adalah kawasan yang tepat dalam pemanfaatannya sebagai RTH. Selain karena letaknya yang berada di tengah Kota Makassar, juga karena padatnya ekosistem mangrove yang tumbuh di sepanjang jalur bantaran sungai. Selain kondisi vegetasi mangrove, pengelolaan ekosistem mangrove sebagai kawasan RTH telah didukung oleh masyarakat pemerintah daerah melalui rencana tata ruang wilayah (RTRW) Kota Makassar terkait penetapan Sungai Tallo sebagai kawasan RTH. Pengelolaan kawasan sempadan sungai Tallo sebagai RTH mampu meningkatkan cadangan oksigen di Kota Makassar, menyerap gas karbon dioksida $\left(\mathrm{CO}_{2}\right)$, serta mampu menahan genangan air ataupun banjir.

Selain manfaat tersebut, pemanfaatan ekosistem mangrove Sungai Tallo yang terletak di tengah Kota Makassar juga memiliki manfaat terkait dengan nilai-nilai yang terkandung di dalamnya. Diantara manfaat tersebut adalah seperti yang dijelaskan oleh Wijanarko (2006) yaitu: (1) Nilai ekologis dan alam: ekosistem mangrove sebagai kawasan terbuka di dalam kota dapat berfungsi sebagai penyaring debu/polutan lainnya, sehingga kualitas udara jadi lebih baik dan mengurangi kebisingan dari mesin kendaraan, (2) Nilai psikologis: mangrove sebagai kawasan RTH sebagai tempat bagi seseorang untuk menyendiri dan menikmati kesunyian guna melepas lelah sementara pada siang hari sehingga dapat kembali bekerja pada kondisi psikologis yang lebih baik. Hal ini dapat dilakukan di kawasan sekitar Sungai Tallo terutama di daerah Lakkang yang merupakan daerah wisata dengan kualitas udara yang lebih baik karena ditumbuhi oleh berbagai vegetasi pohon terutama mangrove jenis Nypa dan Rhizophora, (3) Nilai sosial budaya: penduduk Kota Makassar biasanya melakukan interaksi sosial dengan masyarakat yang hidup di sekitar Sungai Tallo khususnya daerah Lakkang dan menyaksikan pertunjukan seni dan budaya dari masyarakat setempat yang diselenggarakan oleh kelompok sanggar seni Daeng Rilakkang. Melalui pertunjukan ini masyarakat Kota Makassar membangun keakraban dengan masyarakat Desa Lakkang sehingga fungsi sosial dapat berjalan dengan baik, (4) Nilai estetika: nilai keindahan pada kawasan RTH yang terkait dengan tata ruang kota. Intervensi manusia pada RTH akan menentukan nilai estetika tersebut.

\section{Pengelolaan Ekosistem Mangrove sebagai Mitigasi Gas Rumah Kaca}

Mitigasi gas rumah kaca atau perubahan iklim dapat didefinisikan sebagai upaya yang dilakukan untuk mengurangi dampak atau risiko yang ditimbulkan oleh gas rumah kaca yaitu perubahan iklim global. Pengelolaan yang tepat terhadap ekosistem mangrove sebagai upaya mitigasi gas rumah kaca dapat dilakukan dengan melindungi dan menjaga ekosistem mangrove melalui beberapa alternatif pengelolaan baik sebagai kawasan konservasi, ekowisata atau sebagai ruang terbuka hijau. Alternatif-alternatif pengelolaan tersebut pada dasarnya berfungsi untuk menjaga dan melestarikan ekosistem mangrove sehingga fungsi-fungsi biologi, fisika-kimia maupun ekonominya tetap terjaga tak terkecuali fungsi mangrove sebagai penyimpan dan penyerap gas karbon dioksida.

Ekosistem mangrove di Sungai Tallo Kota Makassar berpotensi menyerap karbon dioksida $\left(\mathrm{CO}_{2}\right)$ sebesar 351.02 tonCO $\mathrm{C}_{2} /$ ha. Potensi tersebut harus senantiasa dijaga bahkan dikembangkan sebagai upaya untuk mengurangi dampak perubahan iklim global. Upaya yang dapat dilakukan oleh pemerintah beserta masyarakat dalam pengelolaan mangrove untuk memitigasi gas rumah kaca dapat dibagi menjadi dua yaitu (1) mitigasi nonfisik: penetapan regulasi terhadap pengelolaan mangrove baik sebagai kawasan konservasi maupun ekowisata, serta larangan untuk menebang atau mengonversi lahan mangrove sebagai kawasan pemukiman atau kawasan lain yang cenderung merusak ekosistem mangrove, dan (2) mitigasi fisik: penanaman mangrove (penghijauan) pada lahan-lahan potensial sesuai kriteria kehidupan mangrove. 


\section{KESIMPULAN}

Total serapan karbon mangrove di Sungai Tallo Kota Makassar sebesar 351.02 tonCO $2 /$ ha, suplai oksigen $255.29 \mathrm{O}_{2}$-equivalent/ha, dan potensi pemanasan global sebesar $252.41 \mathrm{mg} / \mathrm{m}^{2} / \mathrm{jam}$ yang terdiri dari 194.33 $\mathrm{mg} / \mathrm{m}^{2} /$ jam gas $\mathrm{CO}_{2}, 15.76 \mathrm{mg} / \mathrm{m}^{2} / \mathrm{jam}$ gas $\mathrm{CH}_{4}$, dan $42.33 \mathrm{mg} / \mathrm{m}^{2} / \mathrm{jam}$ gas $\mathrm{N}_{2} \mathrm{O}$. Hasil analisis persepsi dan partisipasi masyarakat menunjukkan bahwa sekitar $89 \%$ masyarakat mendukung pemerintah selaku pemangku kebijakan dalam pengelolaan ekosistem mangrove sebagai RTH. Hal ini menunjukkan bahwa ekosistem mangrove di Sungai Tallo sangat sesuai dikelola untuk RTH sebagai penyerap GRK khususnya gas karbon dan penyuplai oksigen sehingga dapat berperan pada upaya mitigasi perubahan iklim.

\section{UCAPAN TERIMA KASIH}

Penulis mengucapkan terima kasih kepada Lembaga Pengelola Dana Pendidikan (LPDP) Kementerian Keuangan yang telah memberikan bantuan dana kepada penulis pertama sehingga penelitian ini dapat berjalan dengan lancar.

\section{DAFTAR PUSTAKA}

[IPCC] Intergovernmental Panel on Climate Change. 1990. The Intergovernmental Panel on Climate Change Scientific Assessment. Cambridge (GB): Cambridge University Press.

[IPCC] Intergovernmental Panel on Climate Change. 2001. Climate Change 2001: The Scientific Basis. Cambridge (GB): Cambridge University Press.

[IPCC] Intergovernmental Panel on Climate Change. 2007. Mitigation of Climate Change. Cambridge (GB): Cambridge University Press.

[KLH] Kementerian Lingkungan Hidup. 2012. Pedoman Penyelenggaraan Inventarisasi Gas Rumah Kaca Nasional [Buku I Pedoman Umum]. Jakarta (ID): KLH.

Alemayehu F, Richard O, Wasonga MK. 2014. Assesment of mangroves covers change and biomass in Mide Creek, Kenya. Open Journal of Forestry. 4(4): 398-413.

Allen DE, Dalal RC, Rennenberg H, Meyer RL, Reeves S, Schmidt S. 2007. Spatial and temporal variation of nitrous oxide and methane flux between subtropical mangrove sediments and the atmosphere. Soil Biology and Biochemistry. 39: 622-631.

Biswas H, Mukhopadhyay SK, Sen S, Jana TK. 2007. Spatial and temporal pattern of methane dynamics in the tropical mangrove dominated estuary, NE coast of Bay of Bengal, India. Journal of Marine Systems. 68: 55-64.

Davidson EA. 2009. The contribution of manure and fertilizer nitrogen to atmospheric nitrous oxide since 1860. Natural Geoscience. 2(9): 659-662.

Davidson EA, Keller M, Erickson, HE, Verchot LV, Veldkamp E. 2000. Testing a conceptual model of soil emissions of nitrous and nitric oxides. Bioscience. 50: 667-680.

DeFries RS, Richard AH, Mattew CH, Christoper BF, David S, John T. 2002. Carbon emissions from tropical deforestation and regrowth based on satelite observation for the 1980s. PNAS. 99(22): 14256-14261.

Dunne JA, Jackson SC, Harte J. 2013. Greenhouse effect. Encyclopedia of Biodiversity. 4: 277-293. doi: http://dx.doi.org/10.1016/B978-0-12-384719-5.00068-X.

Hairiah K, Rahayu S. 2007. Pengukuran Karbon Tersimpan di Berbagai Macam Penggunaan Lahan. Malang (ID): World Agroforestry Centre.

Heriyanto NM, Subiandono R. 2012. Komposisi dan struktur tegakan, biomassa dan potensi kandungan karbon hutan mangrove di taman nasional alas purwo. Jurnal Penelitian Hutan dan Konservasi Alam. 9(1): 023-032.

Ilman M, Dargusch P, Dart P, Onrizal. 2016. A historical analysis of the drivers of loss and degradation of Indonesia's mangroves. Land Use Policy. 54: 448-459. 
Iswahyudi, Kusmana C, Hidayat A, Noorachmat BP. 2020. Lingkungan biofisik hutan mangrove di Kota Langsa, Aceh. Journal of Natural Resources and Environmental Management. 10(1): 98-110. doi: http://dx.doi.org/10.29244/jpsl.10.1. 98-110.

Komiyama A, Ong JE, Poungparn S. 2008. Allometry, biomass and productivity of mangrove forest: a. review. Aquatic Botany. 89: 128-137.

Oni, Kusmana C, Basuni S. 2019. Success story rehabilitasi ekosistem mangrove di Pantai Karangsong Kabupaten Indramayu. Journal of Natural Resources and Environmental Management. 9(3): 447-487. doi: http://dx.doi.org/10.29244/jps1.9.3.477-487.

Pemerintah Indonesia. 2007. Undang-Undang No. 26 Tahun 2007 tentang Penataan Ruang. Jakarta (ID): Sekretariat Negara.

Rachmawati D, Setyobudiandi I, Hilmi E. 2014. Potensi estimasi karbon tersimpan pada vegetasi mangrove di wilayah pesisir Muara Gembong, Kabupaten Bekasi. Omni Akuatika. 13(19): 85-91.

Rahman, Efendi H, Rusmana I. 2017. Estimasi stok dan serapan karbon pada mangrove di Sungai Tallo, Makassar. Jurnal Ilmu Kehutanan. 11: 19-28.

Rahman, Yulianda F, Effendi H, Rusmana I, Wardiatno Y. 2018. Fluks gas rumah kaca $\mathrm{CO}_{2}, \mathrm{CH}_{4}$, dan $\mathrm{N}_{2} \mathrm{O}$ pada lahan ekosistem mangrove di Sungai Tallo Makassar. Jurnal Biologi Tropis. 18(2): 149-158.

Rahman, Yulianda F, Rusmana I, Wardiatno Y. 2019. Production ratio of seedlings and density status of mangrove ecosystem in coastal areas of Indonesia. Advances in Environmental Biology. 13(6): 13-20.

Rahman, Wardiatno Y, Yulianda F, Rusmana I. 2020. Socio-ecologycal system of carbon-based mangrove ecosystem on the coast of West Muna Regency, Southeast Sulawesi, Indonesia. AACL Bioflux. 13(2): 518-528.

Riani E. 2012. Perubahan Iklim dan Kehidupan Biota Akuatik: Dampak pada bioakumulasi bahan berbahaya dan beracun dan reproduksi. Bogor (ID): IPB Pr.

Rifqi M, Widigdo B, Wardiatno Y, Mashar A, Adianto W. 2020a. The daily variance of $\mathrm{CO}_{2}$ and $\mathrm{CH}_{4}$ emmission from shrimp ponds. IOP Conference Series: Earth and Environmental Science. 420: 1-9.

Rifqi M, Widigdo B, Wardiatno Y, Mashar A, Adianto W. 2020b. $\mathrm{CO}_{2}$ and $\mathrm{CH}_{4}$ flux from the water interface of three shrimp culture technologies. AACL Bioflux. 13(2): 605-617.

Rijal S. 2008. Kebutuhan ruang terbuka hijau di Kota Makassar Tahun 2017. Jurnal Hutan dan Masyarakat. (8)1: 65-77.

Siddique HRM, Hossain M, Chowdhury KRM. 2012. Allometric relationship for estimating above-ground biomass of Aegialitis rotundifolia Roxb. of Sundarbans mangrove forest, in Bangladesh. Journal of Forestry Research. 23(1): 23-28.

Sotomayor D, Corredor JE, Morell JM. 1994. Methane flux from mangrove soils along the southwestern coast of Puerto Rico. Estuaries and Coastal. 17(1): 140-147.

Wijanarko B. 2006. Kemungkinan penerapan co-management dalam pengelolaan ruang terbuka hijau di pantai utara Kota Surabaya [tesis]. Semarang (ID): Universitas Diponegoro. 